\title{
Stigma of People Living with HIV/AIDS and Its Related Factors among Health Students in UIN Jakarta
}

\author{
Sandrawati ${ }^{1}$, Narila Mutia Nasir ${ }^{2 *}$, Raihana Nadra Alkaff ${ }^{3}$, Laily Hanifah ${ }^{4}$ \\ \{sandrawati285@gmail.com, narilamutia@uinjkt.ac.id ${ }^{2}$, raihana.alkaff@uinjkt.ac.id ${ }^{3}$, \\ laily.hanifah@gmail.com ${ }^{4}$ \} \\ *corresponding author
}

Public Health Study Program, Faculty of Health Sciences, UIN Syarif Hidayatullah Jakarta Ciputat, 15419, Indonesia ${ }^{1,2,3,4}$

\begin{abstract}
The challenge of HIV/AIDS problems in Indonesia is stigma and discrimination against people living with HIV/AIDS (PLWHA). This study was aimed to determine factors related to stigma to PLWHA among health student in UIN Syarif Hidayatullah Jakarta, Indonesia. This research used a cross sectional study design involving 155 health students that were selected randomly as respondents. Data were collected utilizing questionnaire through google form then analyzed by performing Chi-square test. Results showed that $60.6 \%$ of respondents still had stigmatize against PLWHA. Poor knowledge $(\mathrm{p}$ value $=0.035)$, influence of peer attitudes $(\mathrm{p}$ value $=0.002)$, and parent's attitude $(\mathrm{p}$ value $=0.003$ ) had significantly associated with stigma to PLWHA. It is recommended that health students have to improve their knowledge about HIV/AIDS with reliable and valid source of information in order not to be easily influenced by the attitude of parents and peers regarding stigma of PLWHA.
\end{abstract}

Keywords: Health Students, HIV/AIDS, Indonesia, Stigma

\section{Introduction}

Human Immunodeficiency Virus / Acquired Immune Deficiency Syndrome (HIV/AIDS) is one of the most serious public health problems in the world. According to WHO, globally, 37.9 million people were living with HIV at the end of 2018 [1]. The global prevalence of HIV among adults aged 15-49 worldwide living with HIV is $0.8 \%$ [2]. In Indonesia, HIV/AIDS is found in 407 districts/cities or around $80 \%$ of all districts/cities in Indonesia. Banten is one of provinces in Indonesia that reports the high number of HIV cases. The reported case from 1987 to June 2019 in Banten was 8,967 cases and placed Banten as the 10th rank of the province that reported the most HIV cases in Indonesia. Furthermore, the number of AIDS cases reported in the province from 1987 to June 2019 was reached 3,063 cases [3].

One of the biggest obstacles in the prevention and control of HIV/AIDS in Indonesia is the stigma against People Living With HIV/AIDS (PLWHA) [4,5]. The existence of stigma against PLWHA has an impact on the termination, refusal, or non-compliance in the treatment of HIV/AIDS [6]. Makmur's study in 2017 revealed that stigma was occurred in the community and carried out by either family, colleagues, schoolmate, religious leaders, or health workers [7]. Research by Sofia found that $70 \%$ of health workers had stigma to PLWHA by health 
workers [8]. PLWHA who has experienced being stigmatized by health workers may withdraw coming to health services, which can aggravate their condition and lead to death.

The study by Yannus found that $54.3 \%$ of nursing student at Jember University had a high stigma against PLWHA [9]. It implies that the stigma of PLWHA among health workers may occur before they become health workers, such as during they are studying as health students. Therefore, this study aims to determine factors related to stigma to PLWHA among health student in UIN Jakarta, Indonesia.

\section{Method}

This research was a quantitative study using a cross-sectional study design. The ethical approval for this study was obtained from the Ethical Committee of Faculty of Health Sciences UIN Syarif Hidayatullah Jakarta, Indonesia with number of approval Un.01/F.10/KP.01.1/KE.SP/04.08.019/2020. The minimum sample size in this study was calculated using the hypothesis test with the difference of two proportion formula with $5 \%$ significance level and $90 \%$ power of test. Thus, the number of respondents in this study was 155. The 3rd and 4th year students from public health, pharmacy, medical, and nursing study program were involved as respondents in this study. We selected the 3rd and 4th year health students as respondents since they already had more experience dealing with patients and/or the community as part of their field works according to curriculum. Thus, they might have more chances meeting PLWHA.

Data were collected online using google form. The proportional random sampling was carried out to select the respondents for each study program. The researcher contacted the names of students who were selected as respondents, then the researcher provided an explanation through online media about the research conducted to ask their willingness to become respondents by filling in the google form. Using statistical software, the data were analyzed by performing chi-square test.

\section{Result}

Table 1. Stigma against PLWHA among Health Students of UIN Jakarta

\begin{tabular}{llc}
\hline $\begin{array}{l}\text { Stigma against } \\
\text { PLWHA }\end{array}$ & $\mathbf{n}$ & $\begin{array}{c}\text { Frequency } \\
\text { \% }\end{array}$ \\
\hline High Stigma & 94 & 60.6 \\
Low Stigma & 61 & 39.4 \\
Total & $\mathbf{1 5 5}$ & $\mathbf{1 0 0}$ \\
\hline
\end{tabular}

Based on Table 1 above, it is known that among 155 respondents, $60.6 \%$ of them had high stigma against PLWHA. Of $39.4 \%$ of the students had low stigma in this issue. 
Table 2. Related factors on Stigma against PLWHA among Health Students of UIN Jakarta

\begin{tabular}{|c|c|c|c|c|c|c|c|}
\hline \multirow[t]{3}{*}{ Related Factor } & \multicolumn{4}{|c|}{ The Stigma against PLWHA } & \multirow{2}{*}{\multicolumn{2}{|c|}{ Total }} & \multirow[t]{3}{*}{$\mathrm{p}$ value } \\
\hline & \multicolumn{2}{|c|}{ High Stigma } & \multicolumn{2}{|c|}{ Low Stigma } & & & \\
\hline & $\mathrm{n}$ & $\%$ & $\mathrm{n}$ & $\%$ & $\mathrm{n}$ & $\%$ & \\
\hline \multicolumn{8}{|l|}{ Gender } \\
\hline Female & 53 & 61.6 & 33 & 38.4 & 86 & 100 & \multirow[b]{2}{*}{0.909} \\
\hline Male & 41 & 59.4 & 28 & 40.6 & 69 & 100 & \\
\hline \multicolumn{8}{|c|}{ Experience of Meet PLWHA } \\
\hline No & 48 & 62.3 & 29 & 37.7 & 77 & 100 & \multirow[b]{2}{*}{0.792} \\
\hline Yes & 46 & 59.0 & 32 & 41.0 & 78 & 100 & \\
\hline \multicolumn{8}{|c|}{ Knowledge of HIV/AIDS } \\
\hline Poor & 53 & 69.7 & 23 & 30.3 & 76 & 100 & \multirow[b]{2}{*}{$0.035^{*}$} \\
\hline Good & 41 & 51.9 & 38 & 48.1 & 79 & 100 & \\
\hline \multicolumn{8}{|c|}{ Exposure to Information on HIV/AIDS } \\
\hline Less Exposed & 20 & 69.0 & 9 & 31.0 & 29 & 100 & \multirow[b]{2}{*}{0.420} \\
\hline Exposed & 74 & 58.7 & 52 & 41.3 & 126 & 100 & \\
\hline \multicolumn{8}{|l|}{ Peer Attitude } \\
\hline Negative & 59 & 72.8 & 22 & 27.2 & 81 & 100 & \multirow[b]{2}{*}{$0.002 *$} \\
\hline Positive & 35 & 47.3 & 39 & 52.7 & 74 & 100 & \\
\hline \multicolumn{8}{|l|}{ Attitude of Parents } \\
\hline Negative & 64 & 71.1 & 26 & 28.9 & 90 & 100 & \multirow[b]{2}{*}{$0.003 *$} \\
\hline Positive & 30 & 46.2 & 35 & 53.8 & 65 & 100 & \\
\hline
\end{tabular}

*Statistically significant

The analysis shows that there was no significant relationship between stigma against PLWHA and gender ( $p$ value 0.909), experience with PLWHA ( $p$ value 0.792), and information exposure ( $p$ value 0.420 ). There was a significant relationship between stigma against PLWHA and knowledge about HIV/AIDS ( $p$ value 0.035 ), peer attitudes ( $p$ value 0.002 ), and parents' attitudes ( $\mathrm{p}$ value 0.003 ).

\section{Discussion}

The results of this study indicated that the prevalence of stigma against PLWHA among health students at UIN Jakarta is high, $60.6 \%$ them had high stigma against PLWHA. The common stigma found in the field were the opinion that HIV/AIDS patients tend to have multiple sexual partners, PLWHA who are infected through sexual intercourse are guiltier than PLWHA who are infected through blood transfusions, and HIV/AIDS patients themselves have caused their own health problems. The stigmatization also occurred because they believe that 
most of HIV/AIDS patients are infected through risky behavior, such as drug abuse user. Thus, the PLWHA should be the one who responsible for getting the virus.

The high stigma against PLWHA could decrease the quality of care, the quality of life of patients, and the involvement of patients in the care process [10]. This is because PLWHA, who have had experiences of being stigmatized by health workers, will be reluctant to participate in health services for themselves. It might interfere the HIV/AIDS prevention programs.

\section{Gender}

The results of this study found there was no significant relationship between gender and stigma against PLWHA among health students of UIN Jakarta. It was in line with Kharimaturrahmah and Rostini's research [11,12]. This can be caused by the existence of other stigma factors that affect a person's mindset, such as education level, knowledge level, and others. This indicate that both men and women are likely to stigmatize PLWHA.

\section{Experience of Meeting PLWHA}

Based on the results analysis, there was also no significant relationship between the experience of meeting PLWHA and the stigma against PLWHA among health students at the Faculty of Medicine and the Faculty of Health Sciences, UIN Jakarta. The results of this study was different with the Rostini's research which found that there was a significant relationship between the experience of meeting PLWHA and the stigma against PLWHA [12]. Widyasih states that the experience of meeting PLWHA forms attitudes in students and may lead to nonstigmatizing behavior [13]. However, in this study, it was found that the experience of meeting PLWHA was not significantly related to PLWHA.

\section{Knowledge of HIV / AIDS}

This study found a significant relationship between knowledge of HIV/AIDS and the stigma against PLWHA among health students at the Faculty of Medicine and the Faculty of Health Sciences, UIN Jakarta. The results of this study were in line with Kharimaturrahmah's research which found that knowledge was significantly related to the stigma against PLWHA, where respondents who had poor knowledge tend to have higher chance to do stigma than respondents who had good knowledge [11]. The similar result was also found in Sapruddin's study among 192 midwifery students [14]. Knowledge of HIV/AIDS might affect a person's attitude towards PLWHA. This is in accordance with Aggleton which states that one of the causes of stigma against PLWHA is a misunderstanding of how HIV is transmitted and low knowledge of HIV/AIDS prevention [15].

\section{Exposure to Information on HIV / AIDS}

The result of the study showed that there was no significant relationship between exposure to information about HIV/AIDS and stigma against PLWHA among respondents. The similar result was indicated by the Rostini [12]. Shaluhiyah's research also found that there was no significant relationship between access to information about HIV / AIDS and stigma against PLWHA [16]. This is because the source of knowledge can be obtained from various sources of information that can be accessed from various media. However, in this study, researchers did not measure the quality of the information sources obtained and how much information was obtained from the media, but only asked whether or not the respondents had received information about HIV/AIDS in existing media. 


\begin{abstract}
Attitude of Parents
There was a significant relationship between the attitudes of parents and stigma towards PLWHA among health students of UIN Jakarta. Study by Kharimaturrahmah found that students who did stigma to PLWHA were students who had parents with negative attitudes towards PLWHA [11]. Shaluhiyah's research also revealed that people whose families had negative attitudes towards PLWHA were high likely to do the stigma than respondents who had positive family attitudes towards PLWHA [16]. The attitude could be influenced by parental care. A child's attitudes are highly affected by his or her own experiences, but it is also established by modeling the parental attitudes [17]. It is because family is the first environment for the development of children.
\end{abstract}

\title{
Peer Attitude
}

A significant relationship was indicated between peer attitudes and stigma towards PLWHA in this study. Students who have negative peers towards PLWHA have a higher risk of doing stigma compared to students who have positive peers' attitude towards PLWHA. The results of this study are in line with research by Kharimaturrahmah which found that there was a significant relationship between peer attitudes and stigma towards PLWHA among students [11]. Tianingrum's study found that there was a significant relationship between peer influence and stigmatizing attitudes [18]. Students who were influenced by their peers about HIV/AIDS were more likely to have stigma than students who were not influenced by their peers. The attitude of peer groups might affect the person's attitude [17]. This is because the second environment after family for teenagers which have high influence is peers.

\section{Conclusion}

This study concluded that $60.6 \%$ health student at UIN Jakarta had the high stigma against people living with HIV/AIDS. Knowledge about HIV/AIDS, parental attitudes, and peer attitudes showed the crucial role in the process of stigmatization. It is recommended that health students have to improve their knowledge about HIV/AIDS with reliable and valid source of information in order not to be easily influenced by the attitude of parents and peers regarding stigma of PLWHA.

\section{References}

[1] WHO.: HIV/AIDS. Accessed from http://www.searo.who.int/topics/hiv_aids/en/ on 1 October 2019

[2] UNAIDS.: Women and HIV- A spotlight on adolescent girls and young women. Accessed from https://www.unaids.org/en/resources/documents/2019/women-and-hiv on 1 October 2019

[3] Kemenkes.: Laporan Perkembangan HIV/AIDS \& PIMS Di Indonesia Januari-Juni 2019. Ditjen P2P Kementrian Kesehatan RI (2019)

[4] Hati,K, Shaluhiyah, Z, Suryoputro,A.: Stigma Masyarakat Terhadap ODHA di Kota Kupang Provinsi NTT. Vol. 12, pp. 62-77. Jurnal Promosi Kesehatan Indonesia (2017)

[5] Sari,EP.: Determinan yang Mempengaruhi Stigma Terhadap Prang Dengan HIV/AIDS (ODHA) Pada Wanita Pernah Kawin Usia 15-49 Tahun di Indonesi (Analisis lanjut data SDKI 2012). Skripsi Universitas Indonesia (2015)

[6] Situmeang,B, Syarif,S, Mahkota,R.: Hubungan Pengetahuan HIV/AIDS dengan Stigma terhadap Orang dengan HIV/AIDS di Kalangan Remaja 15-19 Tahun di Indonesia (Analisis Data SDKI Tahun 2012). Vol. 1, pp. 35-43. Jurnal Epidemiologi Kesehatan Indonesia (2017) 
[7] Makmur,R.: Strategi Komunikasi Orang Dengan HIV AIDS (ODHA) Menghadapi Stigma Masyarakat. Vol. 1, pp. 68-83. Jurnal Komunikasi (2017)

[8] Sofia, R.: Stigma dan Diskriminasi terhadap ODHA (Studi Pada Tenaga Kesehatan di Puskesmas Tanah Pasir Aceh Utara). Vol. 1, pp. 79-89 Jurnal Kedokteran dan Kesehatan Malikussaleh (2015)

[9] Yannus, AC.: Intensi Melakukan Stigma Pada Orang Dengan HIV/AIDS (ODHA) Oleh Mahasiswa Fakultas Keperawatan Universitas ember. Skripsi Universtas Jember (2018)

[10] Wilandika.: Penilaian Stigma Petugas Kesehatan Pada Orang Dengan HIV/AIDS (ODHA) Pada Salah Satu Puskesmas di Bandung. Vol. 10, pp. 7-15. Journal UMM (2019)

[11] Kharimaturrahmah, I.: Pengaruh Sikap Teman dan Orangtua terhadap Stigma ODHA oleh Mahasiswa Keperawatan STIKes Kota Yogyakarta. Vol. 8, pp. 131-141. Jurnal Promosi Kesehatan Indonesia (2013)

[12] Rostini.: Faktor-Faktor Yang Berhubungan Dengan Sikap Petugas Puskesmas Terhadap Orang Dengan Hivaids (Odha) Dalam Pelayanan Kesehatan Hiv-Aids Di Kota Bandung Tahun 2010. Tesis Universitas Indonesia (2010)

[13] Widyasih \& Suherni.: Faktor-Faktor Yang Mempengaruhi Stigma Mahasiswa Poltekkes Kemenkes Yogyakata Terhadap Orang Dengan HIV/AIDS (ODHA). Vol. 11, pp. 59-63. Journal Health Technology (2015)

[14] Sapruddin.: Pengetahuan Dan Sikap Stigma Mahasiswa Kebidanan Stikes Kuningan Terhadap Orang Dengan Hiv/Aids (ODHA). Vol. 4, pp. 23-25. Jurnal Ilmu-Ilmu Kesehatan Bhakti Husada Kuningan (2015)

[15] Aggleton, P, \& Parker.: A Conceptual Framework And Basis For Action HIV/AIDS Stigma And Discrimination. World AIDS Campaign (2003)

[16] Shaluhiyah, Z, Musthofa,SB, Widjanarko,B.: Stigma Masyarakat terhadap Orang dengan HIV/AIDS. Vol. 9, pp. 324-329. Jurnal Kesehatan Masyarakat Nasional (2015)

[17] Oskamp \& Schultz.: Attitude and Opinion. Lawrence Erlbaum. London: Associates Publishers (2005)

[18] Tianingrum.: Pengaruh Keterpaparan Informasi terhadap Stigma HIV/AIDS Pada Pelajar SMA. Vol. 6, pp 22-31. Jurnal Ilmu Kesehatan (2018) 